\title{
Improving User Comfort Classroom at the Kalimantan Institute of Technology with Maintenance Factors
}

\author{
O. L. Sari ${ }^{1 *}$, B. Basyaruddin², B. Z. F. Elwore ${ }^{3}$. \\ ${ }^{1 * 2,3}$ Department of Civil Engineering and Planning Kalimantan Institute of Technology. \\ Email: ${ }^{1 *}$ oryza@lecturer.itk.ac.id
}

\begin{tabular}{ll} 
A R T I C L E I N F O \\
\hline $\begin{array}{l}\text { Article History : } \\
\text { Article entry }\end{array}$ 16-03-2021 \\
Article revised $: 31-03-2021$ \\
Article received $: 23-07-2021$ \\
\hline
\end{tabular}

\section{Keywords :}

Comfort, Linear Regression, Maintenance, SPSS.

IEEE Style in citing this article : [3] S. Susanto, H. Hendy, B. Winarno, and A. I. Candra, "Measurement Of Occupational Safety And Health Risk Levels Of Kadiri University LP3M Building," U KaRsT Univ. Kadiri Ris. Tek. Sipil, vol. 5, no. 1, pp. 126-141, 2020, doi: 10.1016/j.proeng.2016.11.753.A.

\begin{abstract}
A B S T R A C T
In building construction, the implementation of maintenance activities plays an important role in the quality of the building. By carrying out these activities regularly, it's hoped to minimize and prevent damage to buildings and make users feel comfortable. Kalimantan Institute of Technology must have comfortable study spaces. This study aims to determine the effect of the class maintenance factor on the user's comfort level. The analysis brought by determining what factors are influencing, these factors influence, and the most dominant factors affecting the most. Primary data was obtained by distributing questionnaires to respondents, secondary data inactive students, and lecturers at the Kalimantan Institute of Technology, and supporting research data in ministerial regulations, books, research journals, and others. The data analysis process uses IBM SPSS as an auxiliary program with multiple linear regression analysis methods. Based on the research and data processing conducted, it's concluded that 8 factors influence the maintenance, namely the maintenance of user comfort by $80.8 \%$ and the variable maintenance of the room walls. The room wall maintenance variable is the most dominant factor influencing the comfort of classroom users. Knowing these factors can implement optimal implementation to support the comfort of class users at the Kalimantan Institute of Technologists.
\end{abstract}

\section{Introduction}

Maintenance is an activity to repair and replace parts of components, buildings, infrastructure, and building materials so that the building remains functional and curative after a problem or damage occurs [1]. Proper and appropriate maintenance activities can save time and costs, provide long-term benefits, and support better performance. Buildings can achieve a service life if they are cared for and maintained as planned [2][3]. 
Maintenance of a building can be interpreted as an activity carried out to maintain the building and preventive maintenance. A building is a physical form of the result of a construction work that integrated with the place of its domicile, functions as a place for humans to carry out an activity, whether for a place to live or occupy, business activities, religious activities, culture, special activities or social activities [4].

Comfort can be defined as a condition of fulfilling basic human needs, namely the need for relief (needs have been met), transcendence (a state associated with something that exceeds problems and pain), and tranquility. (a sense of satisfaction that can improve daily appearance) [5].

In previous studies that became the author's reference, each of these studies discussed two things, namely the level of comfort and the influence factor of maintenance. In previous research that discusses the level of comfort, as sustainable construction tends to focus on environmental sustainability, it is likely that this focus will also lead to a sustainable workplace in terms of health, satisfaction, and well-being [6][7][8]. Some discuss related factors that affect building maintenance. Starting from case studies of offices, residential, housing, government residential [9][10][11]. Regarding affecting factors, there are discussions related to building maintenance in government residential and similar discussions with case studies in tertiary institutions [12][13]. Another case study is related to the factors that affect the maintenance of public buildings oriented to environmental or climate problems, humidity, design errors, unavailability of skilled labor, and comfort of office workers [14][15][16].

The Kalimantan Institute of Technology, as a large campus, must have a comfortable lecture room for its users because comfortable room conditions affect the course of lecture activities. As the building ages, it is necessary to maintain and care for the building to keep it proper and comfortable. In the classrooms of buildings A and B on the ITK campus, it's still found that some components of the classroom were damaged, which affected the user's comfort.

Class maintenance activities need to be implemented to support educational activities, which addressed knowing what maintenance factors affect the comfort level of classroom users in buildings A and B. Determine the factor of classroom maintenance in buildings A and B which has the most dominant influence on user comfort.

\section{Research Method}

\subsection{Research Sites}

The research location is in building A and B of the Kalimantan Institute of Technology 
campus. The campus is an engineering campus located on J1. Soekarno Hatta, KM. 15, Karang Joang, North Balikpapan, Balikpapan, East Kalimantan. The research location can be seen in Figure 1 below:

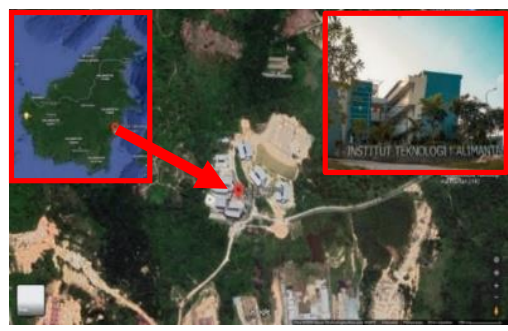

Source : Maps of Kalimantan Institute of Technology

(Google Earth, 2020)

Figure 1. Research Sites Location on Kalimantan Institut of Technology

\subsection{Preliminary Survey}

A minimum number of experts can be used as much as possible and ask for opinions 3 people [17]. In this study, to ascertain the variables, the authors carried out activities such as consultation, verification, interviews, and filling out questionnaires to 5 experts with data that can be seen in Table 1 as follows:

Table 1. Expert Respondent Data.

\begin{tabular}{ccccc}
\hline No. & Position & Education & Work Experience & Project Involvement \\
\hline 1 & Project Manager & Bachelor Degree & $>20$ Year & $>10$ Project \\
2 & Lecturer & Post Graduate & $>20$ Year & $8-10$ Project \\
3 & Inspector/Surveyor & Vocational & $10-20$ Year & $5-7$ Project \\
4 & Section Chief & Bachelor Degree & $5-10$ Year & $>10$ Project \\
5 & Supervisor & Bachelor Degree & $10-20$ Year & $>10$ Project \\
\hline
\end{tabular}

Source : Processed Researchers (2021)

\subsection{Population and Samples}

In the research carried out, there were populations, respondents, and samples in which the population in this study were students and lecturers of the Kalimantan Institute of Technology, totaling 2728 people. This study obtained a sample of 348 students and lecturers at the Kalimantan Institute of Technology.

\subsection{Sampling Techniques}

In the research carried out, the technique used in sampling is the random sampling technique (random sampling). Slovin's formula use to determine the number of samples in the study [18], the solving formula, which can see in below:

$\mathrm{n}=\frac{\mathrm{N}}{1+\mathrm{Ne}^{2}}$ 
Where:
$\mathrm{n}=\quad$ Number of Samples.
$\mathrm{N}=$ Number of Populations.
$\mathrm{e} \quad=\quad$ Error Tolerance Limits.

\subsection{Research Variable}

The independent variables in this study are the building maintenance factors for the lecture buildings used in the questionnaire, which can be seen in Table 2 below:

Table 2. Independent Variable.

\begin{tabular}{|c|c|c|c|c|}
\hline No. & Variable & Indicator & Information & Reference \\
\hline \multirow[t]{2}{*}{$\mathrm{X}_{1}$} & \multirow[t]{2}{*}{$\begin{array}{l}\text { Maintenance of the Lighting } \\
\text { System }\end{array}$} & $\begin{array}{l}\text { Neat placement of } \\
\text { electrical installation } \\
\text { cables }\left(\mathrm{X}_{1.1}\right)\end{array}$ & $\begin{array}{l}\text { The placement of the } \\
\text { power cables is neat } \\
\text { and unobtrusive }\end{array}$ & \multirow[t]{2}{*}[4]{} \\
\hline & & $\begin{array}{l}\text { Lighting in the room } \\
\qquad\left(\mathrm{X}_{1.2}\right)\end{array}$ & $\begin{array}{l}\text { The lighting in the } \\
\text { room is bright and not } \\
\text { dark }\end{array}$ & \\
\hline \multirow[t]{2}{*}{$\mathrm{X}_{2}$} & \multirow[t]{2}{*}{ Maintenance of Ceiling } & Ceiling condition $\left(\mathrm{X}_{2.1}\right)$ & $\begin{array}{l}\text { The ceiling is well } \\
\text { maintained and does } \\
\text { not experience } \\
\text { cracks/breaks }\end{array}$ & \multirow[t]{2}{*}{ [4] } \\
\hline & & Ceiling cleanliness $\left(\mathrm{X}_{2.2}\right)$ & $\begin{array}{c}\text { The ceiling is not } \\
\text { stained, and the color } \\
\text { does not fade }\end{array}$ & \\
\hline \multirow[t]{2}{*}{$\mathrm{X}_{3}$} & \multirow[t]{2}{*}{$\begin{array}{l}\text { Maintenance of Air } \\
\text { Conditioning System }\end{array}$} & $\begin{array}{l}\text { Availability of fan/AC } \\
\left(\mathrm{X}_{3.1}\right)\end{array}$ & Fan/AC available & \multirow[t]{2}{*}{ [4] } \\
\hline & & Fan/AC works $\left(\mathrm{X}_{3.2}\right)$ & $\begin{array}{c}\text { The fan/AC is usable } \\
\text { and works fine }\end{array}$ & \\
\hline \multirow[t]{3}{*}{$\mathrm{X}_{4}$} & \multirow[t]{3}{*}{$\begin{array}{l}\text { Maintenance of Classroom } \\
\text { Cleanliness }\end{array}$} & Floor cleanliness $\left(\mathrm{X}_{4.1}\right)$ & $\begin{array}{l}\text { Floor not dirty } \\
\text { and dusty }\end{array}$ & \multirow[t]{3}{*}{ [4] } \\
\hline & & $\begin{array}{l}\text { Availability of trash cans } \\
\left(\mathrm{X}_{4.2}\right)\end{array}$ & Clear enough & \\
\hline & & $\begin{array}{c}\text { Arrangement of tables, } \\
\text { chalkboard, and chairs } \\
\left(\mathrm{X}_{4.3}\right)\end{array}$ & $\begin{array}{c}\text { Tables, blackboards, } \\
\text { and chairs neatly } \\
\text { arranged }\end{array}$ & \\
\hline \multirow[t]{2}{*}{$\mathrm{X}_{5}$} & \multirow[t]{2}{*}{ Maintenance of Frames } & Frames condition $\left(\mathrm{X}_{5.1}\right)$ & $\begin{array}{c}\text { The frame is well } \\
\text { maintained }\end{array}$ & \multirow[t]{2}{*}[4]{} \\
\hline & & $\begin{array}{l}\text { Lock, Hinge, and Latch } \\
\text { Conditions }\left(\mathrm{X}_{5.2}\right)\end{array}$ & $\begin{array}{l}\text { Locks, hinges, and } \\
\text { latch do not rust and } \\
\text { work well }\end{array}$ & \\
\hline \multirow[t]{3}{*}{$\mathrm{X}_{6}$} & \multirow[t]{3}{*}{$\begin{array}{l}\text { Maintenance of Electronic } \\
\text { System }\end{array}$} & $\begin{array}{l}\text { The condition of the } \\
\text { socket and switch }\left(\mathrm{X}_{6.1}\right)\end{array}$ & $\begin{array}{l}\text { Sockets and switches } \\
\text { can function properly }\end{array}$ & \multirow[t]{2}{*}{ [4] } \\
\hline & & $\begin{array}{l}\text { Internet network quality } \\
\qquad\left(\mathrm{X}_{6.2}\right)\end{array}$ & $\begin{array}{l}\text { The quality of the } \\
\text { internet has sufficient } \\
\text { speed }\end{array}$ & \\
\hline & & $\begin{array}{c}\text { Condition of LCD } \\
\text { Projector / Screen Media } \\
\left(\mathrm{X}_{6.3}\right)\end{array}$ & $\begin{array}{l}\text { Produces images with } \\
\text { quality that are not } \\
\text { blurry and suitable for } \\
\text { use }\end{array}$ & [19] \\
\hline \multirow[t]{3}{*}{$\mathrm{X}_{7}$} & \multirow[t]{3}{*}{ Maintenance of Room Wall } & $\begin{array}{l}\text { Paint color on the walls } \\
\left(\mathrm{X}_{7.1}\right)\end{array}$ & $\begin{array}{l}\text { The paint color does } \\
\text { not fade and fade }\end{array}$ & \multirow[t]{3}{*}[4]{} \\
\hline & & $\begin{array}{l}\text { Cleanliness of the walls } \\
\left(\mathrm{X}_{7.2}\right)\end{array}$ & $\begin{array}{c}\text { Walls have no stains or } \\
\text { streaks }\end{array}$ & \\
\hline & & Walls condition $\left(\mathrm{X}_{7.3}\right)$ & $\begin{array}{l}\text { Walls are not cracked } \\
\text { or chipped }\end{array}$ & \\
\hline
\end{tabular}




\begin{tabular}{|c|c|c|c|c|}
\hline No. & Variable & Indicator & Information & Reference \\
\hline \multirow[t]{2}{*}{$\mathrm{X}_{8}$} & Maintenance of Furniture & $\begin{array}{l}\text { Furniture condition } \\
\qquad\left(\mathrm{X}_{8.1}\right)\end{array}$ & $\begin{array}{l}\text { Furniture is functional } \\
\text { and well maintained }\end{array}$ & [4] \\
\hline & & $\begin{array}{l}\text { Cleanliness of the } \\
\text { furniture }\left(\mathrm{X}_{8.2}\right)\end{array}$ & $\begin{array}{c}\text { Furniture color does } \\
\text { not fade, and there are } \\
\text { no stains }\end{array}$ & \\
\hline
\end{tabular}

Source : Processed Researchers (2021)

The below is the dependent variable in the research carried out, attached to Table 3:

Table 3. Dependent Variable.

\begin{tabular}{ccccc}
\hline No. & Variable & Indicator & Information & Reference \\
\hline $\mathrm{Y}_{1}$ & User Comfort Level $\left(\mathrm{Y}_{1.1}\right)$ & Classroom User Comfort & Clear Enough & - \\
\hline Source & $:$ Processed Researchers $(2021)$ & &
\end{tabular}

\subsection{Questionnaire Survey}

The step in this stage is the drafting of a questionnaire, and then the pilot survey process is carried out after the draft questionnaire is made, in which can use the pilot survey sample at least $10 \%$ of the total sample size [18]. In the research, a questionnaire used a Likert scale for measurements. The Likert scale to determine the value of each variable can be seen in Table 3 below:

Table 3. Variable Assessment Using a Likert Scale.

\begin{tabular}{cc}
\hline Variable Assessment by Respondent & Scoring Scale \\
\hline Very Irrelevant & 1 \\
\hline Irrelevant & 2 \\
\hline Quite Relevant & 3 \\
\hline Relevant & 4 \\
\hline Very Relevant & 5 \\
\hline
\end{tabular}

Source : Processed Researchers (2021)

\subsection{Processing and Analysis of Data}

In conducting the validity and reliability tests, the SPSS software was used as an auxiliary program[20]. The following is the correlation coefficient at the $r$ value found in Table 4:

Table 4. Correlation Coefficient at $r$ Value.

\begin{tabular}{cc}
\hline Correlation Coefficient at $\mathbf{r}$ Value & Relationship Level \\
\hline $0,00-0,199$ & Very Low \\
\hline $0,20-0,399$ & Low \\
\hline $0,40-0,599$ & Strong Enough \\
\hline $0,60-0,799$ & Strong \\
\hline $0,80-1,00$ & Very Strong \\
\hline
\end{tabular}

Source : [21] 
In research conducted by the authors, the reliability test has a function to ensure that the data or questionnaire used can be said to be reliable or not. Cronbach's Alpha as a method is measured on a scale from 0 to 1 . An instrument in research is called reliable if the Cronbach's Alpha value is > 0,6 [22][23]. Below is the attached Cronbach's Alpha value and can be seen in Table 5:

Table 5. Cronbach's Alpha Value.

\begin{tabular}{cc}
\hline Cronbach's Alpha Value & Score \\
\hline $0,00-0,20$ & Less Reliable \\
\hline $0,21-0,40$ & Rather Reliable \\
\hline $0,41-0,60$ & Quite Reliable \\
\hline $0,61-0,80$ & Reliable \\
\hline $0,81-1,00$ & Very Reliable \\
\hline
\end{tabular}

Source : [22]

The data from the questionnaire obtained by the researcher were analyzed using multiple linear regression analysis, then performed multiple linear regression analysis, hypothesis testing ( $\mathrm{t}$ test and $\mathrm{F}$ test), analysis of the coefficient of determination, then the dominant test.

\section{Results and Discussions}

\subsection{Preliminary Survey Results}

The preliminary survey results carried out on the experts have obtained responses related to the level of influence of classroom maintenance indicators in buildings A and B of the Kalimantan Institute of Technology campus. If the mean value is higher, the indicator is more relevant [17]. The results of the responses are attached using the mean test shown in Table 6:

Table 6. Expert Response on Classroom Maintenance Indicators for Building A and B.

\begin{tabular}{|c|c|c|c|c|c|c|c|c|}
\hline Code & $\begin{array}{l}\text { Indicator } \\
\end{array}$ & 1 & 2 & 3 & 4 & 5 & Mean & Score \\
\hline $\mathrm{X}_{1.1}$ & $\begin{array}{l}\text { Tidiness of Placement of Electrical Installation } \\
\text { Cables }\end{array}$ & 4 & 5 & 4 & 4 & 5 & 4,4 & Relevant \\
\hline $\mathrm{X}_{2.1}$ & Ceiling Condition & 5 & 4 & 5 & 4 & 4 & 4,4 & Relevant \\
\hline $\mathrm{X}_{6.3}$ & LCD Projector Condition & 4 & 4 & 3 & 5 & 5 & 4,2 & Relevant \\
\hline $\mathrm{X}_{7.3}$ & Walls Condition & 4 & 4 & 4 & 4 & 5 & 4,2 & Relevant \\
\hline $\mathrm{X}_{2.2}$ & Ceiling Cleanliness & 4 & 3 & 5 & 4 & 4 & 4 & Relevant \\
\hline $\mathrm{X}_{4.1}$ & Floor Cleanliness & 4 & 3 & 5 & 4 & 4 & 4 & Relevant \\
\hline $\mathrm{X}_{4.3}$ & Table, Chalkboard, and Chair Arrangement & 4 & 4 & 4 & 4 & 4 & 4 & Relevant \\
\hline $\mathrm{X}_{6.2}$ & Internet Network Quality & 4 & 3 & 5 & 5 & 3 & 4 & Relevant \\
\hline $\mathrm{X}_{7.1}$ & Paint Color on the Wall & 4 & 3 & 4 & 5 & 4 & 4 & Relevant \\
\hline $\mathrm{Y}_{1.1}$ & User Comfort Level & 4 & 4 & 4 & 4 & 4 & 4 & Relevant \\
\hline $\mathrm{X}_{3.2}$ & Fan/Air Conditioner Function & 4 & 4 & 4 & 4 & 3 & 3,8 & Quite Relevant \\
\hline $\mathrm{X}_{4.2}$ & Availability of Trash Cans & 3 & 4 & 5 & 3 & 4 & 3,8 & Quite Relevant \\
\hline $\mathrm{X}_{5.2}$ & Lock, Hinge, and Latch Conditions & 3 & 4 & 4 & 5 & 3 & 3,8 & Quite Relevant \\
\hline $\mathrm{X}_{6.1}$ & Receptacles and Switches Condition & 4 & 4 & 3 & 3 & 4 & 3,6 & Quite Relevant \\
\hline
\end{tabular}




\begin{tabular}{clccccccc}
\hline Code & Indicator & $\mathbf{1}$ & $\mathbf{2}$ & $\mathbf{3}$ & $\mathbf{4}$ & $\mathbf{5}$ & Mean & Score \\
\hline $\mathrm{X}_{7.2}$ & Walls Cleanliness & 3 & 3 & 4 & 4 & 4 & $\mathbf{3 , 6}$ & Quite Relevant \\
\hline $\mathrm{X}_{8.2}$ & Furniture Cleanliness & 3 & 3 & 4 & 5 & 3 & $\mathbf{3 , 6}$ & Quite Relevant \\
\hline $\mathrm{X}_{1.2}$ & Indoor Lighting & 2 & 4 & 4 & 3 & 4 & $\mathbf{3 , 4}$ & Quite Relevant \\
\hline $\mathrm{X}_{5.1}$ & Frame Condition & 4 & 4 & 4 & 2 & 3 & $\mathbf{3 , 4}$ & Quite Relevant \\
\hline $\mathrm{X}_{3.1}$ & Availability of Fan/Air Conditioner & 3 & 3 & 5 & 2 & 3 & $\mathbf{3 , 2}$ & Quite Relevant \\
\hline $\mathrm{X}_{8.1}$ & Furniture's Condition & 2 & 3 & 4 & 4 & 3 & $\mathbf{3 , 2}$ & Quite Relevant \\
\hline
\end{tabular}

Source : Processed by Researchers, 2021

In each indicator, the mean score must be $>3,00$ so that the indicator can be used as an indicator that determines making a decision. The 20 indicators for the maintenance of classrooms in buildings A and B on the Kalimantan Institute of Technology campus can be relevant for use in the questionnaire survey.

\subsection{Pilot Survey Results}

The number of samples used in the pilot survey was $10 \%$ of the total sample size [24]. With a total of 35 samples, the result can be seen in Table 7 below:

Table 7. Response to the Pilot Survey of Classroom Maintenance for Buildings A and B

\begin{tabular}{|c|c|c|c|}
\hline Code & Indicator & Mean (R1-R35) & Score \\
\hline $\mathrm{X}_{1.2}$ & Indoor Lighting & 4,5 & Relevant \\
\hline $\mathrm{X}_{3.1}$ & Availability of Fan/Air Conditioner & 4,5 & Relevant \\
\hline $\mathrm{X}_{6.1}$ & Receptacles and Switches Condition & 4,5 & Relevant \\
\hline $\mathrm{X}_{1.1}$ & Tidiness of Placement of Electrical Installation Cables & 4,4 & Relevant \\
\hline $\mathrm{X}_{4.2}$ & Availability of Trash Cans & 4,3 & Relevant \\
\hline $\mathrm{X}_{3.2}$ & Fan/Air Conditioner Function & 4,3 & Relevant \\
\hline $\mathrm{X}_{6.2}$ & Internet Network Quality & 4,3 & Relevant \\
\hline $\mathrm{X}_{2.1}$ & Ceiling Condition & 4,2 & Relevant \\
\hline $\mathrm{X}_{4.1}$ & Floor Cleanliness & 4,2 & Relevant \\
\hline $\mathrm{X}_{6.3}$ & LCD Projector Condition & 4,2 & Relevant \\
\hline $\mathrm{X}_{5.2}$ & Lock, Hinge, and Latch Conditions & 4,2 & Relevant \\
\hline $\mathrm{X}_{7.2}$ & Walls Cleanliness & 4,1 & Relevant \\
\hline $\mathrm{X}_{8.1}$ & Furniture's Condition & 4,1 & Relevant \\
\hline $\mathrm{X}_{7.3}$ & Walls Condition & 4,1 & Relevant \\
\hline $\mathrm{X}_{7.1}$ & Paint Color on the Wall & 4 & Relevant \\
\hline $\mathrm{X}_{2.2}$ & Ceiling Cleanliness & 4 & Relevant \\
\hline $\mathrm{X}_{8.2}$ & Furniture Cleanliness & 4 & Relevant \\
\hline $\mathrm{X}_{4.3}$ & Table, Chalkboard, and Chair Arrangement & 3,9 & $\begin{array}{c}\text { Quite } \\
\text { Relevant }\end{array}$ \\
\hline $\mathrm{X}_{5.1}$ & Frame Condition & 3,8 & $\begin{array}{c}\text { Quite } \\
\text { Relevant }\end{array}$ \\
\hline $\mathrm{Y}_{1.1}$ & User Comfort Level & 3,8 & $\begin{array}{c}\text { Quite } \\
\text { Relevant }\end{array}$ \\
\hline
\end{tabular}

Source : Processed by Researchers, 2021

The mean pilot survey filled in by 35 samples obtained a score with relevant and quite relevant information from the pilot survey results. This indicates that respondents can understand the questionnaire, and it is feasible to distribute questionnaires to all respondents. 


\subsection{Questionnaire Survey Data Collection Result}

From the questionnaire survey distributed by the author, a sample/data of 348 respondents obtained. The percentage of respondents by generation can be seen in Figure 2 below:

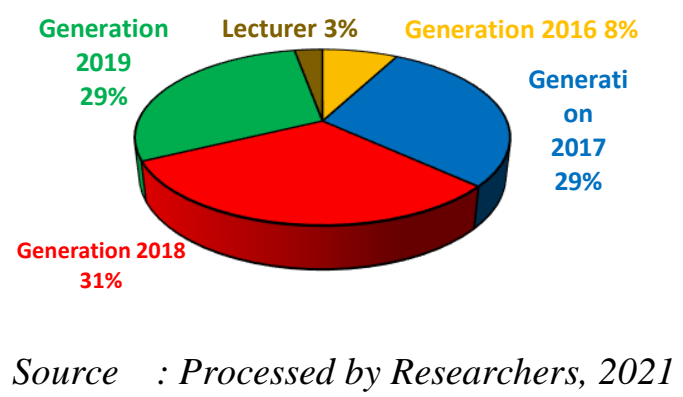

Figure 2. Percentage Diagram of Respondents by Position

From the percentage diagram of respondents based on batches, it is known that the 2018 batch of students filled out the questionnaire the most with a percentage of $31 \%$, followed by the 2019 and 2017 batches at $29 \%$, the 2016 class at $8 \%$, and $3 \%$ for lecturers.

\subsection{Validity Test}

The validity test aims to determine whether each variable/indicator of a questionnaire submitted to respondents can be said to be valid or not. The results of the validity test that have have been done can be seen in Table 8 below:

Table 8. Results of the Validity Test of Classroom Maintenance Variables

\begin{tabular}{lcccc}
\hline \multicolumn{1}{c}{ Variable } & Indicator & $\mathbf{r}_{\text {count }}$ & $\mathbf{r}_{\text {table }}$ & Information \\
\hline Maintenance of the Lighting System & $X_{1.1}$ & $\mathbf{0 , 4 6 3}$ & 0,113 & Valid \\
$\left(X_{1}\right)$ & $X_{1.2}$ & $\mathbf{0 , 3 8 8}$ & 0,113 & Valid \\
\hline Ceiling Maintenance & $X_{2.1}$ & $\mathbf{0 , 6 9 2}$ & 0,113 & Valid \\
(X) & $X_{2.2}$ & $\mathbf{0 , 7 0 9}$ & 0,113 & Valid \\
\hline Air Conditioning System Maintenance & $X_{3.1}$ & $\mathbf{0 , 5 4 6}$ & 0,113 & Valid \\
(X) & $X_{3.2}$ & $\mathbf{0 , 7 0 5}$ & 0,113 & Valid \\
\hline Room Cleanliness & $X_{4.1}$ & $\mathbf{0 , 5 0 7}$ & 0,113 & Valid \\
Maintenance & $X_{4.2}$ & $\mathbf{0 , 4 5 4}$ & 0,113 & Valid \\
(X) & $X_{4.3}$ & $\mathbf{0 , 4 9 7}$ & 0,113 & Valid \\
\hline Maintenance of frames & $X_{5.1}$ & $\mathbf{0 , 6 3 7}$ & 0,113 & Valid \\
(X) & $X_{5.2}$ & $\mathbf{0 , 5 7 9}$ & 0,113 & Valid \\
\hline Electronic System & $X_{6.1}$ & $\mathbf{0 , 6 4 9}$ & 0,113 & Valid \\
Maintenance & $X_{6.2}$ & $\mathbf{0 , 6 2 7}$ & 0,113 & Valid \\
(X6) & $X_{6.3}$ & $\mathbf{0 , 6 7 1}$ & 0,113 & Valid \\
\hline Maintenance of the Walls & $X_{7.1}$ & $\mathbf{0 , 6 6 5}$ & 0,113 & Valid \\
of the room & $X_{7.2}$ & $\mathbf{0 , 6 1 6}$ & 0,113 & Valid \\
(X) & $X_{7.3}$ & $\mathbf{0 , 6 6 6}$ & 0,113 & Valid \\
\hline
\end{tabular}




\begin{tabular}{lcccc}
\hline Variable & Indicator & $\mathbf{r}_{\text {count }}$ & $\mathbf{r}_{\text {table }}$ & Information \\
\hline $\begin{array}{l}\text { Furniture Maintenance } \\
\left(\mathrm{X}_{8}\right)\end{array}$ & $\mathrm{X}_{8.1}$ & $\mathbf{0 , 6 9 7}$ & 0,113 & Valid \\
\hline $\begin{array}{l}\text { Classroom User Convenience } \\
\left(\mathrm{Y}_{1}\right)\end{array}$ & $\mathrm{X}_{8.2}$ & $\mathbf{0 , 6 6 1}$ & 0,113 & Valid \\
\hline
\end{tabular}

Source : IBM SPSS, 2021

Based on the table above, it can be seen that the values of $r$ count and $r_{\text {table }}$ obtained from the results of the Validity Test. The value of $r_{\text {table }}$ obtained a value of 0.113 , and for all $r$ count values, the variables/indicators have $r_{\text {count }}>r_{\text {table }}(0.113)$.

\subsection{Reliability Test}

The following is attached the Reliability Test results, which can be seen in the following Table 9 below:

Table 9. Results of Reliability Test of Classroom Maintenance Variables

\begin{tabular}{lccc}
\hline \multicolumn{1}{c}{ Variable } & Indicator & Cronbach's Alpha & Information \\
\hline Maintenance of the Lighting System & $\mathrm{X}_{1.1}$ & $\mathbf{0 , 9 1 2}$ & Very Reliable \\
$\left(\mathrm{X}_{1}\right)$ & $\mathrm{X}_{1.2}$ & $\mathbf{0 , 9 1 3}$ & Very Reliable \\
\hline Ceiling Maintenance & $\mathrm{X}_{2.1}$ & $\mathbf{0 , 9 0 7}$ & Very Reliable \\
$\left(\mathrm{X}_{2}\right)$ & $\mathrm{X}_{2.2}$ & $\mathbf{0 , 9 0 6}$ & Very Reliable \\
\hline Air Conditioning System Maintenance & $\mathrm{X}_{3.1}$ & $\mathbf{0 , 9 1 0}$ & Very Reliable \\
$\left(\mathrm{X}_{3}\right)$ & $\mathrm{X}_{3.2}$ & $\mathbf{0 , 9 0 6}$ & Very Reliable \\
\hline Room Cleanliness & $\mathrm{X}_{4.1}$ & $\mathbf{0 , 9 1 1}$ & Very Reliable \\
Maintenance & $\mathrm{X}_{4.2}$ & $\mathbf{0 , 9 1 2}$ & Very Reliable \\
$\left(\mathrm{X}_{4}\right)$ & $\mathrm{X}_{4.3}$ & $\mathbf{0 , 9 1 1}$ & Very Reliable \\
\hline Maintenance of frames & $\mathrm{X}_{5.1}$ & $\mathbf{0 , 9 0 8}$ & Very Reliable \\
$\left(\mathrm{X}_{5}\right)$ & $\mathrm{X}_{5.2}$ & $\mathbf{0 , 9 0 9}$ & Very Reliable \\
\hline Electronic System & $\mathrm{X}_{6.1}$ & $\mathbf{0 , 9 0 7}$ & Very Reliable \\
Maintenance & $\mathrm{X}_{6.2}$ & $\mathbf{0 , 9 0 9}$ & Very Reliable \\
$\left(\mathrm{X}_{6}\right)$ & $\mathrm{X}_{6.3}$ & $\mathbf{0 , 9 0 7}$ & Very Reliable \\
\hline Maintenance of the Walls & $\mathrm{X}_{7.1}$ & $\mathbf{0 , 9 0 7}$ & Very Reliable \\
of the room & $\mathrm{X}_{7.2}$ & $\mathbf{0 , 9 0 8}$ & Very Reliable \\
$\left(\mathrm{X}_{7}\right)$ & $\mathrm{X}_{7.3}$ & $\mathbf{0 , 9 0 7}$ & Very Reliable \\
\hline Furniture Maintenance & $\mathrm{X}_{8.1}$ & $\mathbf{0 , 9 0 6}$ & Very Reliable \\
$\left(\mathrm{X}_{8}\right)$ & $\mathrm{X}_{8.2}$ & $\mathbf{0 , 9 0 7}$ & Very Reliable \\
\hline Classroom User Convenience & $\mathrm{Y}_{1.1}$ & $\mathbf{0 , 9 0 3}$ & Very Reliable \\
(Y & & & \\
\hline
\end{tabular}

Source : IBM SPSS, 2021

Based on the reliability test results attached in the table, can concluded variables/indicators of classroom maintenance of buildings A and B of the Kalimantan Institute of Technology

\subsection{Classic Assumption Test}

The below are the results of the analysis and further data testing carried out in this study.

\section{a. Normality Test}

The following is attached the Normality Test results which can be seen in the following 
Table 10 below:

Table 10. Results of the Normality Test

\begin{tabular}{cccc}
\hline & \multicolumn{3}{c}{ Kolmogrov-Smirnov } \\
\cline { 2 - 4 } & Statistic & df & Sig. \\
\hline Average & 0,051 & 348 & $\mathbf{0 , 2 6 5}$
\end{tabular}

Source : IBM SPSS, 2021

The Normality Test value can normally be distributed if the significance value is > 0.05 , and it is said to not normally be distributed if the significance value is $<0.05$. Based on the normality test results above, we obtained a significance value of $0.265>0.05$. can be concluded that the residual value is normally distributed.

\section{b. Multicollinearity Test}

The following is attached the Multicollinearity Test results, which can be seen in the following Table 11 below:

Table 11. Results of Multicollinearity Test

\begin{tabular}{|c|c|c|c|c|c|c|c|c|}
\hline & \multirow{2}{*}{ Model } & \multicolumn{2}{|c|}{$\begin{array}{l}\text { Unstandardized } \\
\text { Coefficients }\end{array}$} & \multirow{2}{*}{$\begin{array}{c}\begin{array}{c}\text { Standardized } \\
\text { Coefficients }\end{array} \\
\text { Beta } \\
\end{array}$} & \multirow[t]{2}{*}{$\mathbf{t}$} & \multirow[t]{2}{*}{ Sig. } & \multicolumn{2}{|c|}{ Collineartity Statistics } \\
\hline & & B & Std. Error & & & & Tolerance & VIF \\
\hline \multirow[t]{20}{*}{1} & (Constant) & $-0,157$ & 0,123 & & $-1,279$ & 0,202 & & \\
\hline & $\mathrm{X}_{1.1}$ & 0,043 & 0,022 & 0,052 & 1,978 & 0,049 & 0,744 & 1,344 \\
\hline & $\mathrm{X}_{1.2}$ & 0,042 & 0,022 & 0,051 & 1,958 & 0,051 & 0,772 & 1,395 \\
\hline & $\mathrm{X}_{2.1}$ & 0,039 & 0,021 & 0,072 & 1,818 & 0,070 & $\mathbf{0 , 3 3 3}$ & 3,002 \\
\hline & $\mathrm{X}_{2.2}$ & 0,031 & 0,025 & 0,051 & 1,261 & 0,208 & 0,316 & 3,162 \\
\hline & $\mathrm{X}_{3.1}$ & 0,039 & 0,018 & 0,061 & 2,131 & 0,034 & 0,639 & $\mathbf{1 , 5 6 5}$ \\
\hline & $\mathrm{X}_{3.2}$ & 0,069 & 0,020 & 0,117 & 3,429 & 0,001 & 0,453 & 2,209 \\
\hline & $\mathrm{X}_{4.1}$ & 0,005 & 0,023 & 0,006 & 0,222 & 0,825 & 0,646 & 1,548 \\
\hline & $\mathrm{X}_{4.2}$ & 0,102 & 0,022 & 0,128 & 4,555 & 0,000 & 0,664 & 1,506 \\
\hline & $\mathrm{X}_{4.3}$ & 0,080 & 0,023 & 0,100 & 3,484 & 0,001 & 0,636 & $\mathbf{1 , 5 7 3}$ \\
\hline & $\mathrm{X}_{5.1}$ & 0,088 & 0,025 & 0,114 & 3,490 & 0,001 & 0,491 & 2,038 \\
\hline & $\mathrm{X}_{5.2}$ & 0,011 & 0,026 & 0,015 & 0,440 & 0,660 & 0,471 & 2,125 \\
\hline & $\mathrm{X}_{6.1}$ & 0,075 & 0,020 & 0,113 & 3,804 & 0,000 & 0,598 & 1,672 \\
\hline & $X_{6.2}$ & 0,036 & 0,017 & 0,067 & 2,090 & 0,037 & 0,510 & 1,959 \\
\hline & $\mathrm{X}_{6.3}$ & 0,027 & 0,021 & 0,041 & 1,314 & 0,190 & 0,527 & 1,896 \\
\hline & $X_{7.1}$ & 0,066 & 0,024 & 0,095 & 2,781 & 0,006 & 0,448 & 2,232 \\
\hline & $\mathrm{X}_{7.2}$ & 0,082 & 0,023 & 0,120 & 3,590 & 0,000 & 0,466 & 2,147 \\
\hline & $\mathrm{X}_{7.3}$ & 0,063 & 0,024 & 0,090 & 2,683 & 0,008 & 0,468 & 2,136 \\
\hline & $\mathrm{X}_{8.1}$ & 0,082 & 0,026 & 0,105 & 3,089 & 0,002 & 0,452 & 2,211 \\
\hline & $\mathrm{X}_{8.2}$ & 0,063 & 0,028 & 0,079 & 2,261 & 0,024 & 0,433 & 2,312 \\
\hline
\end{tabular}

a. Dependent Variable: User Comfort Level (Y)

Source : IBM SPSS, 2021

For the multicollinearity test, it can be seen in the collinearity statistics section for each independent variable having a tolerance value $>0.1$ and a VIF value $<10.00$, can conclude that the regression model does not occur multicollinearity.

\section{c. Heteroscedasticity Test}

Based on data processing, then the following is attached the Heteroscedasticity Test 
results, which can be seen in the following Table 12 below:

Table 12. Results of Heteroscedasticity Test

\begin{tabular}{llccccc}
\hline \multirow{2}{*}{ Model } & \multicolumn{2}{c}{ Unstandardized Coefficients } & Standardized Coefficients & \multirow{2}{*}{ T } & \multirow{2}{*}{ Sig. } \\
\cline { 2 - 5 } & B & Std. Error & Beta & & 3,198 & $\mathbf{0 , 2 0 2}$ \\
\hline \multirow{2}{*}{1} & (Constant) & 0,172 & 0,054 & 0,055 & 1,076 & 0,283 \\
\cline { 2 - 5 } & Maintenance & 0,001 & 0,001 & &
\end{tabular}

a. Dependent Variable: Abs_Res

Source : IBM SPSS, 2021

For the Glejser test, the basis for decision-making is the value (Sig.) The significance between the independent variables with absolute residual $>0.05$ then the heteroscedasticity problem does not occur, based on the Glejser test table above the significance value is $0.283>0.05$, and it can be concluded that for the regression model, There are no problems or symptoms of heteroscedasticity.

\section{d. Autocorrelation Test}

Based on data processing, then the following is attached the Autocorrelation Test results which can be seen in the following Table 13 below:

Table 13. Results of Autocorrelation Test

\begin{tabular}{rcccccc}
\hline Model & $\boldsymbol{d}$ & $\boldsymbol{d}_{\boldsymbol{l}}$ & $\boldsymbol{d}_{\boldsymbol{u}}$ & $\mathbf{4}-\boldsymbol{d}_{\boldsymbol{l}}$ & $\mathbf{4}-\boldsymbol{d}_{\boldsymbol{u}}$ & Decision \\
\hline Linear & $\mathbf{1 , 8 9 1}$ & 1,780 & 1,864 & 2,220 & 2,136 & There is no autocorrelation \\
\hline Source & $:$ IBM & SPSS, 2021 & & & &
\end{tabular}

From the Durbin-Watson table, the value of $\mathrm{dl}=1.780$ and the value of $\mathrm{du}=1.864$. From the results of the Autocorrelation Test, the value of $d=1.891$, this value is then compared with other values in Table 13, namely the value of $\mathrm{dl}=1.780$, the value of $\mathrm{du}=1.864$, the value of $4-\mathrm{dl}=2.220$, and the value of $4-\mathrm{du}=2.136$, from The comparison, is obtained $1.864(\mathrm{du})<1.891(\mathrm{~d})<2.136(4-\mathrm{du})$, it is concluded that there is no autocorrelation in the regression model.

\subsection{Multiple Linear Regression Analysis}

Multiple linear regression analysis is a test used to test the effect of more than one independent variable on the dependent variable [25]. Based on data processing, then the following is attached the Multiple Linear Regression Analysis results, which can be seen in the following Table 14 below:

Table 14. Results of Multiple Linear Rgression Analysis (Value B)

\begin{tabular}{|c|c|c|c|c|c|c|c|c|}
\hline \multicolumn{9}{|c|}{ Coefficients $^{\mathbf{a}}$} \\
\hline & \multirow{2}{*}{ Model } & \multicolumn{2}{|c|}{$\begin{array}{l}\text { Unstandardized } \\
\text { Coefficients }\end{array}$} & \multirow{2}{*}{$\begin{array}{c}\begin{array}{c}\text { Standardized } \\
\text { Coefficients }\end{array} \\
\text { Beta }\end{array}$} & \multirow{2}{*}{$\mathbf{t}$} & \multirow{2}{*}{ Sig. } & \multicolumn{2}{|c|}{ Collineartity Statistics } \\
\hline & & B & Std. Error & & & & Tolerance & VIF \\
\hline \multirow[t]{7}{*}{1} & (Constant) & $-0,210$ & 0,124 & & $-1,687$ & 0,092 & & \\
\hline & $\mathrm{X}_{1}$ & 0,098 & 0,026 & 0,099 & 3,804 & 0,000 & 0,810 & 1,234 \\
\hline & $\mathrm{X}_{2}$ & $\mathbf{0 , 0 8 9}$ & 0,018 & 0,152 & 4,933 & 0,000 & 0,579 & 1,726 \\
\hline & $\mathrm{X}_{3}$ & 0,110 & 0,022 & 0,156 & 5,068 & 0,000 & 0,581 & 1,722 \\
\hline & $\mathrm{X}_{4}$ & $\mathbf{0 , 1 8 6}$ & 0,026 & 0,202 & 7,251 & 0,000 & 0,713 & 1,403 \\
\hline & $\mathrm{X}_{5}$ & $\mathbf{0 , 0 8 3}$ & 0,024 & 0,101 & 3,427 & 0,001 & 0,635 & 1,574 \\
\hline & $\mathrm{X}_{6}$ & $\mathbf{0 , 1 3 5}$ & 0,023 & 0,188 & 5,906 & 0,000 & 0,548 & 1,824 \\
\hline
\end{tabular}

Improving User Comfort Classroom at the Kalimantan Institute of Technology with Maintenance Factors 


\begin{tabular}{|c|c|c|c|c|c|c|c|}
\hline \multirow{2}{*}{ Model } & \multicolumn{2}{|c|}{$\begin{array}{l}\text { Unstandardized } \\
\text { Coefficients }\end{array}$} & \multirow{2}{*}{$\begin{array}{c}\text { Standardized } \\
\text { Coefficients } \\
\text { Beta }\end{array}$} & \multirow{2}{*}{$\mathbf{t}$} & \multirow{2}{*}{ Sig. } & \multicolumn{2}{|c|}{ Collineartity Statistics } \\
\hline & B & Std. Error & & & & Tolerance & VIF \\
\hline $\mathrm{X}_{7}$ & 0,208 & 0,023 & 0,270 & 8,871 & 0,000 & 0,597 & 1,674 \\
\hline $\mathrm{X}_{8}$ & 0,128 & 0,026 & 0,150 & 4,876 & 0,000 & 0,586 & 1,706 \\
\hline
\end{tabular}

a. Dependent Variable: User Comfort Level (Y)

Source : IBM SPSS, 2021

From the table above, in the multiple linear regression analysis, we want to know how much influence the variable $\mathrm{x}$ has on the $\mathrm{y}$ variable if classroom maintenance activities are carried out.

\subsection{Hypothesis Test ( $t$ Test and $F$ Test)}

Based on data processing, then the following is attached the $t$ Test results which can be seen in the following Table 15 below:

Table 15. Results of Multiple Linear Rgression Analysis ( $t$ Test)

\begin{tabular}{|c|c|c|c|c|c|c|c|c|}
\hline \multicolumn{9}{|c|}{ Coefficients $^{\mathrm{a}}$} \\
\hline & \multirow{2}{*}{ Model } & \multicolumn{2}{|c|}{$\begin{array}{c}\text { Unstandardized } \\
\text { Coefficients }\end{array}$} & \multirow{2}{*}{$\begin{array}{c}\begin{array}{c}\text { Standardized } \\
\text { Coefficients }\end{array} \\
\text { Beta } \\
\end{array}$} & \multirow[t]{2}{*}{$\mathbf{t}$} & \multirow[t]{2}{*}{ Sig. } & \multicolumn{2}{|c|}{ Collineartity Statistics } \\
\hline & & B & Std. Error & & & & Tolerance & VIF \\
\hline \multirow[t]{9}{*}{1} & (Constant) & $-0,210$ & 0,124 & & $-1,687$ & 0,092 & & \\
\hline & $\mathrm{X}_{1}$ & 0,098 & 0,026 & 0,099 & 3,804 & 0,000 & 0,810 & 1,234 \\
\hline & $\mathrm{X}_{2}$ & $\mathbf{0 , 0 8 9}$ & 0,018 & 0,152 & 4,933 & 0,000 & 0,579 & 1,726 \\
\hline & $\mathrm{X}_{3}$ & 0,110 & 0,022 & 0,156 & 5,068 & $\mathbf{0 , 0 0 0}$ & 0,581 & 1,722 \\
\hline & $\mathrm{X}_{4}$ & 0,186 & 0,026 & 0,202 & 7,251 & 0,000 & 0,713 & 1,403 \\
\hline & $\mathrm{X}_{5}$ & $\mathbf{0 , 0 8 3}$ & 0,024 & 0,101 & 3,427 & 0,001 & 0,635 & 1,574 \\
\hline & $\mathrm{X}_{6}$ & 0,135 & 0,023 & 0,188 & 5,906 & 0,000 & 0,548 & 1,824 \\
\hline & $\mathrm{X}_{7}$ & 0,208 & 0,023 & 0,270 & 8,871 & 0,000 & 0,597 & 1,674 \\
\hline & $\mathrm{X}_{8}$ & $\mathbf{0 , 1 2 8}$ & 0,026 & 0,150 & 4,876 & 0,000 & 0,586 & 1,706 \\
\hline
\end{tabular}

a. Dependent Variable: User Comfort Level (Y)

Source : IBM SPSS, 2021

In the t-test table, we want to know whether there is an effect of the $\mathrm{x}$ variable on the $y$ variable that the classroom maintenance variable has a partial effect on user comfort. Based on data processing, then the following is attached the F-Test results, which can be seen in the following Table 16 below:

Table 16. Results of Multiple Linear Rgression Analysis (F Test)

\begin{tabular}{ccccccc}
\hline \multicolumn{9}{c}{ ANOVA $^{\mathrm{b}}$} \\
\hline \multirow{2}{*}{1} & Model & Sum of Squares & df & Mean Square & F & Sig. \\
\cline { 2 - 7 } & Regression & 113,142 & 8 & 14,143 & $\mathbf{1 8 3 , 6 3 8}$ & $0,000^{\text {a }}$ \\
\cline { 2 - 8 } & Residual & 26,108 & 339 & 0,077 & & \\
\hline
\end{tabular}

a. Predictors: (Constant), Furniture Maintenance, Lighting System Maintenance, Air

Conditioning System Maintenance, Room Cleanliness Maintenance, Electronic System

Maintenance, Frame Maintenance, Ceiling Maintenance, Electronic System Maintenance.

b. Dependent Variable: User Comfort Level (Y)

Source : IBM SPSS, 2021 
In the $\mathrm{F}$ test table, we want to know whether there is an effect of variable $\mathrm{x}$ on variable $\mathrm{y}$ that the classroom maintenance variable has a partial effect on user comfort.

\subsection{Analysis of the Coefficient of Determination $\left(R^{2}\right.$ Test $)$}

Based on data processing, then the following is attached the Analysis of the Coefficient of Determination ( $\mathrm{R}^{2}$ Test) results which can be seen in the following Table $\mathbf{1 7}$ below:

Table 17. Results of Multiple Linear Rgression Analysis ( $\left.\mathrm{R}^{2} \mathrm{Test}\right)$

\section{Model Summary}

\begin{tabular}{cccccc}
\hline Model & R & R Square & Adjusted R Square & Std. Error of the Estimate & Durbin-Watson \\
\hline 1 & 0,901 & 0,813 & $\mathbf{0 , 8 0 8}$ & 0,278 & 1,912 \\
\hline
\end{tabular}

a. Predictors: (Constant), Furniture Maintenance, Lighting System Maintenance, Air

Conditioning System Maintenance, Room Cleanliness Maintenance, Electronic System

Maintenance, Frame Maintenance, Ceiling Maintenance, Electronic System Maintenance

b. Dependent Variable: User Comfort Level (Y)

Source : IBM SPSS, 2021

From the Multiple Linear Regression Analysis that has it's finished, the Adjusted R Square value is 0.808 . So it can be concluded that the Classroom Maintenance Variable (X) has an effect of $80.8 \%$ on the User Comfort Level (Y). The remaining percentage of $19.2 \%$ is another factor besides the variables studied in this study.

\subsection{Dominant Test}

Based on data processing, then the following is attached the Dominant Test results, which can be seen in the following Table 18 below:

Table 18. The Results of Ordering Independent Variable Beta Values

\begin{tabular}{|c|c|c|}
\hline No & Variabel Bebas & B \\
\hline 1 & Maintenance of Room Walls $\left(\mathrm{X}_{7}\right)$ & $\mathbf{0 , 2 0 8}$ \\
\hline 2 & Room Cleanliness Maintenance $\left(\mathrm{X}_{4}\right)$ & $\mathbf{0 , 1 8 6}$ \\
\hline 3 & Electronic System Maintenance $\left(\mathrm{X}_{6}\right)$ & $\mathbf{0 , 1 3 5}$ \\
\hline 4 & Furniture Maintenance $\left(\mathrm{X}_{8}\right)$ & $\mathbf{0 , 1 2 8}$ \\
\hline 5 & Air Conditioning System Maintenance $\left(\mathrm{X}_{3}\right)$ & $\mathbf{0 , 1 1 0}$ \\
\hline 6 & Lighting System Maintenance $\left(\mathrm{X}_{1}\right)$ & $\mathbf{0 , 0 9 8}$ \\
\hline 7 & Maintenance of Ceiling $\left(\mathrm{X}_{2}\right)$ & $\mathbf{0 , 0 8 9}$ \\
\hline 8 & Maintenance of Frames $\left(\mathrm{X}_{5}\right)$ & $\mathbf{0 , 0 8 3}$ \\
\hline
\end{tabular}

Source: IBM SPSS, 2021

If the value of the Beta coefficient is getting closer to 0 then the relationship of the $\mathrm{X}$ variable and $\mathrm{Y}$ variable can be said to be getting weaker. Based on the table above, the Room Wall Maintenance Variable (X7) is the Independent Variable (X) with a Beta value of 0,208 , which has the most dominant influence on Classroom User Comfort (Y). 


\section{Conclusion and Suggestion}

\subsection{Conclusion}

From the research that researchers have carried out, the following conclusions were obtained:

1. Maintenance factors that affect the comfort level of classrooms A and B classroom users. Room Wall Maintenance, Room Cleanliness Maintenance, Electronic System Maintenance, Furniture Maintenance, Air Conditioning System Maintenance, Lighting System Maintenance, Ceiling Maintenance, and Maintenance Sills.

2. Classroom Maintenance Variables (X) in buildings A and B simultaneously have a significant effect on the User Comfort Level Variable (Y) with a determination coefficient of 0.808 which means that the Classroom Maintenance Variable (X) has an effect of $80.8 \%$ on the variable Classroom User Comfort (Y).

3. Room Wall Maintenance Variable $\left(\mathrm{X}_{7}\right)$ is the most dominant factor affecting the Comfort Level of Classroom Users (Y) in buildings A and B. It is indicated by the room wall maintenance variable (X7) with a value of 0.208 .

\subsection{Suggestion}

Based on the results obtained from the research, it's hoped that the Kalimantan Institute of Technology campus will increase its classroom maintenance activities to increase the comfort level of classroom users in buildings A and B on the Kalimantan Institute of Technology campus. 


\section{References}

[1] H. Mulyandari dan R.A Saputra, Pemeliharaan Bangunan: Basic Skill Facility Management. 2010.

[2] T. Sucipto, Analisis keterandalan bangunan. 2009.

[3] S. Susanto, H. Hendy, B. Winarno, and A. I. Candra, "Measurement Of Occupational Safety And Health Risk Levels Of Kadiri University LP3M Building," U KaRsT Univ. Kadiri Ris. Tek. Sipil, vol. 5, no. 1, pp. 126-141, 2020, doi: 10.1016/j.proeng.2016.11.753.A.

[4] Permen PU No.24/2008, "Permen PU nomor 24 tahun 2008 tentang Pedoman Pemeliharaan Gedung," Permen PU No. 24, p. 16, 2008.

[5] A. Kaushik, M. Arif, P. Tumula, and O. J. Ebohon, "Effect of thermal comfort on occupant productivity in office buildings: Response surface analysis," Build. Environ., vol. 180, p. 107021, 2020, doi: 10.1016/j.buildenv.2020.107021.

[6] A. Smith and M. Pitt, "Sustainable workplaces and building user comfort and satisfaction," J. Corp. Real Estate, vol. 13, no. 3, pp. 144-156, 2011, doi: $10.1108 / 14630011111170436$.

[7] C. C. Full and A. A. Tabassi, "Relationship between Quality of Building Maintenance Management Services for Indoor Environmental Quality and Occupant Satisfaction: Case Study of Bus Terminal Buildings in Penang," SHS Web Conf., vol. 11, p. 01011, 2014, doi: 10.1051/shsconf/20141101011.

[8] A. Shah et al., "The effect of physical employees' performance environment comfort on in office buildings," 2015.

[9] C. Candido, S. Marzban, S. Haddad, M. Mackey, and A. Loder, "Designing healthy workspaces: results from Australian certified open-plan offices," Facilities, vol. 39, no. 5-6, pp. 411-433, 2021, doi: 10.1108/F-02-2020-0018.

[10] B. S. Waziri and B. A. Vanduhe, "Evaluation of Factors Affecting Residential Building Maintenance in Nigeria : Users 'Perspective," Civ. Environ. Res., vol. 3, no. 8, pp. 19$25,2013$.

[11] Andrew, FACTORS AFFECTING HOUSING MAINTENANCE MANAGEMENT COST IN KAKAMEGA MUNICIPALITY, KENYA, vol. 20, no. 7. 2008, pp. 98-105.

[12] O. E. Ogunmakinde, "Analysis of the Factors Affecting Building Maintenance in Goverenment Residential Estates In Akure,” J. Environ. Sci. Resour. Manag., vol. 5, no. 2, pp. 89-103, 2013. 
[13] A. A. Ajayi, "Factors Affecting Maintenance Management of Education Trust Factors Affecting Maintenance Management of Education Trust Fund ( Etf ) Buildings of Tertiary Institutions in Osun State,” no. May, pp. 0-13, 2017.

[14] R. Talib, a G. Ahmad, N. Zakaria, and M. Z. Sulieman, "Assessment of Factors Affecting Building Maintenance and Defects of Public Buildings in Penang, Malaysia," Archit. Res., vol. 4, no. 2, pp. 48-53, 2014, doi: 10.5923/j.arch.20140402.03.

[15] P. M. . \& B. S. O. Ofori. I.. Duodu, "Establishing Factors Influencing Building Maintenance Practices,” J. Econ. Sustain. Dev., vol. 6, no. 24, pp. 184-193, 2015.

[16] M. A. Risanji and R. Raflis, “Analisis Faktor Pemeliharaan Bangunan Gedung Terhadap Kenyamanan Pekerja Kantor,” Potensi J. Sipil Politek., vol. 20, no. 2, p. 98, 2018, doi: 10.35313/potensi.v20i2.1268.

[17] Sugiyono, Metode Penelitian Kuantitatif, Kualitatif dan R\&D., Vol 1. Tek. Ind, 2011.

[18] A. Susanti, R. A. A. Soemitro, H. Suprayitno, and V. Ratnasari, "Searching the Appropriate Minimum Sample Size Calculation Method for Commuter Train Passenger Travel Behavior Survey," J. Infrastruct. Facil. Asset Manag., vol. 1, no. 1, pp. 47-60, 2019, doi: 10.12962/jifam.v1i1.5232.

[19] W. Ervianto, Manajemen Proyek Konstruksi-Edisi Revisi. 2006.

[20] R. Ajiono and H. Wahyudiono, “Analisis Faktor Risiko Lelang Di Bawah Perkiraan Kinerja Kualitas Proyek Konstruksi Bangunan di Kota Trenggalek Jawa Timur,” vol. 2, no. 2, pp. 164-173, 2018.

[21] Purbayu Budi, ANALISIS STATISTIK DENGAN MICROSOFT EXCEL DAN SPSS Dr. PURBAYU BUDI SANTOSA, MS ASHARI, S.E Akt.pdf. 2005.

[22] K. S. Taber, “The Use of Cronbach's Alpha When Developing and Reporting Research Instruments in Science Education," Res. Sci. Educ., vol. 48, no. 6, pp. 1273-1296, 2018, doi: 10.1007/s11165-016-9602-2.

[23] K. Anwar and M. A. Rizqi, "Validity and Reliability Analysis of Assessment for Customer Satisfaction At University of Muhammadiyah Gresik,” pp. 141-152, 2012.

[24] K. Truong, "Pilot Studies: When and How to Conduct Them When Conducting User Studies," GetMobile Mob. Comp. Comm., vol. 20, no. 4, pp. 8-11, 2017.

[25] N. Pandis, "Multiple linear regression analysis," Am. J. Orthod. Dentofac. Orthop., vol. 149, no. 4, p. 581, 2016, doi: 10.1016/j.ajodo.2016.01.012. 